Article

\title{
Religious Nationalism in a Global World
}

\author{
Mark Juergensmeyer \\ Department of Sociology and Global Studies, University of California, Santa Barbara, CA 93106, USA; \\ juergens@global.ucsb.edu
}

Received: 29 December 2018; Accepted: 30 January 2019; Published: 4 February 2019

\begin{abstract}
The rise of new forms of religious nationalism at the end of the 20th and beginning of the 21 st centuries is to a large extent a by-product of globalization. As nation-states are permeated by transnational economics and trends and secular nationalism is challenged by the global diaspora of peoples and cultures, new ethno-religious movements have arisen to shore up a sense of national community and purpose. One can project at least three different futures for religious and ethnic nationalism in a global world: one where religious and ethnic politics ignore globalization, where they rail against it, and where they envision their own transnational futures.
\end{abstract}

Keywords: nationalism; religious movements; secularism; Islamic nationalism; Christian nationalism; Jewish nationalism; Buddhist nationalism; Hindu nationalism; Sikh nationalism

The vote in the UK in favor of Brexit, the election of Donald Trump in the United States, and the ascendancy of Victor Orbán's xenophobic regime in Hungary are all indications that a strident new form of nationalism is sweeping the world in the second decade of the twentieth century. Much of it is interwoven with religion, creating an aggressive cultural nationalism that has asserted itself from Myanmar to the Middle East.

Religious nationalism is not a new phenomenon, however. Beginning in the 1970s, new forms of nationalism based on religion began to appear around the world, defying the legacy of secular nationalism based on the ideas of the European Enlightenment. Initially the independent nation-states that emerged earlier in the 20th century at the end of the colonial era followed the pattern of secularism set during colonial rule, but at the end of the century this began to change. Assertions of religious politics began to arise in the Middle East, South Asia, and elsewhere. Prominent among them was the Islamic revolution in Iran in 1978, in a country that had not been part of a colonial Empire; it created the first modern religious nation-state and set a standard for religious politics that other countries would follow. Religious nationalism was on the rise.

At that time, some twenty-five years ago and shortly after the end of the Cold War, I wrote a book about this rise of religious nationalism, The New Cold War? Religious Nationalism Confronts the Nation State, in which I raised the question of whether the confrontation between these new movements of religious nationalism and the secular state was creating a hostile ideological confrontation on a global scale that, in its own way, was a new Cold War (Juergensmeyer 1993).

Twenty-five years later, I suppose it is time to remove the question mark from my title. This ideological confrontation has persisted and become increasingly more intense. In this essay I will return to my analysis, see what is still relevant and what has changed. Religious nationalism, it appears, is an evolving idea. And it has evolved in tandem with the emergence of globalization as an increasingly dominant motif in the 21st century.

Therein lies a paradox. Globalization is marked by a rapid mobility of peoples, mass migrations, the proliferation of diaspora cultures, and a transnational sense of community provided by internet relationships. Yet despite these features, religious nationalism persists. In fact it seems to flourish in a global world. Religious affiliation, while providing a connection to transnational networks, also 
offers resources for shoring up local identities. Why have limited loyalties and parochial new forms of ethno-religious nationalism surfaced in todays' sea of post-nationality?

History seems poised on the brink of an era of globalization, hardly the time for new national aspirations to emerge. In fact, some observers have cited the appearance of ethnic and religious nationalism in such areas as the former Yugoslavia and the former Soviet Union, Algeria and the Middle East, South Asia, Japan, and among right-wing movements in Europe and the United States as evidence that globalization has not reached all quarters of the globe. But is this really the case? Is it possible to see these quests for local identities and new nationalisms not as anomalies in the homogeneity of globalization, but as further examples of its impact?

Though the impact of globalization was not immediately apparent twenty-five years ago when I wrote The New Cold War?, increasingly it is clear that the paradox of new nationalisms in a global world can be explained, in part, by seeing them as products of one or more of several globalizing forces. In many cases, the new ethnic and religious movements are reactions to globalization. They are responses to the insufficiencies of what is often touted as the world's global political standard: the secular constructs of nationalism that are found not only in Europe and the United States but remain in many parts of the former Third World as vestiges of European colonialism.

In this essay I will look at the responses to old secular nationalisms, which are under siege precisely at a time when they have themselves been weakened by globalization. Their vulnerability has been the occasion for new ethno-religious politics to step into the breach and shore up national identities and purposes in their own distinctive ways. Some forms of ethno-religious politics are global, some are virulently anti-global, and yet others are content with the attempt to create ethno-religious nation-states. Thus, these new forms of ethnic and religious politics will remain paradoxical: sometimes aligned with nationalism, sometimes with transnational ideologies, and in both cases standing in uneasy relationship with the globalizing economic and cultural forces of the post-Cold War world.

\section{Globalization's Assault on Nationalism}

It should not be surprising that new sociopolitical forms are emerging at this moment of history since globalization is redefining virtually everything on the planet. This includes especially those social and political conventions associated with the nation-state. Among other things, global forces are undermining many of the traditional pillars on which the secular nation-state have been based, such as national sovereignty, economic autonomy, and social identity. As it turns out, however, these aspects of the nation-state have been vulnerable to change for some time.

Born as a stepchild of the European Enlightenment, the idea of the modern nation-state is profound and simple: the state is created by the people within a given national territory. Secular nationalism - the ideology that originally gave the nation-state its legitimacy—contends that a nation's authority is based on the secular idea of a social compact of equals rather than on ethnic ties or sacred mandates. It is a compelling idea, one with pretensions of universal applicability. It reached its widest extent of worldwide acceptance in the mid-twentieth century.

But the latter half of the century was a different story. The secular nation-state proved to be a fragile artifice, especially in those areas of the world where nations had been created by retreating colonial powers-in Africa by Britain, Portugal, Belgium, and France; in Latin America by Spain and Portugal; in South and Southeast Asia by Britain, France, the Netherlands, and the United States; and in Eurasia by the Soviet Union. In some cases, boundary disputes led to squabbles among neighboring nations. In others, the very idea of the nation was a cause for suspicion.

Many of these imagined nations-some with invented names such as Yugoslavia, Pakistan, Indonesia, and Iraq-were not accepted by everyone within their territories. In yet other cases, the tasks of administration became too difficult to perform in honest and efficient ways. The newly created nations had only brief histories of prior colonial control to unite them, and after independence they had only the most modest of economic, administrative, and cultural infrastructures to hold their disparate regions together. 
By the 1990s, these ties had begun to fray. The global economic market undercut national economies, and the awesome military technology of the U.S. and NATO reduced national armies to border patrols. More significantly, the rationale for the nation-state came into question. With the collapse of the Soviet Union and the post-colonial, post-Vietnam critique of Western democracy, the secular basis for the nation-state seemed increasingly open to criticism. In some instances, such as in Yugoslavia, when the ideological glue of secular nationalism began to dissolve, the state fell apart.

The effect of what I called in my earlier book "the loss of faith in secular nationalism" was devastating (Juergensmeyer 1993). Throughout the world, it seemed, nationalism was subject to question, and the scholarly community joined in the task of trying to understand the concept in a post-Cold War and transnational era. At that time, other scholars joined me in seeing the rise of religious and ethnic nationalism as part of the unfinished business of rejecting colonialism and European modernity (Anderson 1983; Gottlieb 1993; Kotkin 1994; Smith 1995; Tamir 1993; Young 1993). Part of the reason for nationalism's shaky status in the late 20th century was that it was transported to many parts of the world in the cultural baggage of what Jürgen Habermas has called "the project of modernity" (Habermas 1987, p. 148) -an ascription to reason and a progressive view of history that many thought to be obsolete. In a multicultural world where a variety of views of modernity are in competition, the very concept of a universal model of secular nationalism became a matter of lively debate.

By the beginning of the 21st century, however, increasingly a host of scholars, including myself, have come to see the rise of ethno-religious nationalism not just as a rejection of modernity but also as a response to postmodernity and its new transnational form, globalization (James 2006; Judis 2018; Juergensmeyer 2008; Greenfeld 2017; Hurd 2017, Shah et al. 2012; Toft et al. 2011). Globalization challenges the modern idea of nationalism in a variety of ways. These challenges are varied because globalization is multifaceted: the term, after all, refers not to any one thing but to a series of processes. The term embraces not only the global reach of transnational businesses but also their labor supply, currency, and financial instruments. In a broader sense, it also refers to the planetary expansion of media and communications technology, popular culture, and environmental concerns. Ultimately, it also includes a sense of global citizenship and a commitment to world order.

When one speaks of "globalization," therefore, it is useful to specify which aspect of it one has in mind. It is possible that people in a particular region of the world will experience one kind of globalization but not others. For instance, countries that are brought into contact with economic globalization-by supplying labor for the commodity chains of globalized production-may not experience the globalization of culture and citizenship. In fact, the advent of economic globalization may threaten local identities in such a way as to encourage the protection of local cultures and social identities, sometimes in hostile and defensive ways.

My own studies have demonstrated that some of the most intense movements for ethnic and religious nationalism arise in nations where local leaders have felt exploited by the global economy or believe that somehow the benefits of economic globalization have passed them by (Juergensmeyer et al. 2015; Juergensmeyer 2017). The global shifts in economic and political power that occurred following the break-up of the Soviet Union and the sudden rise of Asian economies have had significant social repercussions. The public sense of insecurity that has come in the wake of these changes has been felt especially in areas economically devastated by the changes, including those nations and regions that had been under the dominance of the Soviet Union.

These shifts led to a crisis of national purpose in less-developed nations as well. A new, postcolonial generation no longer believed in the Westernized vision of India's Nehru or Egypt's Nasser. Rather, it wanted to complete the process of decolonialization by asserting the legitimacy of their countries' own traditional values in the public sphere and constructing a national identity based on indigenous culture (Addi 2017; Chatterjee 1993; Farhadian 2005). This eagerness was made all the more keen when they observed the global media assault of Western music, videos, and films 
that satellite television beams around the world, and which threaten to obliterate local and traditional forms of cultural expression.

In other cases, it has been a different kind of globalization-the emergence of multicultural societies through global diasporas of peoples and cultures, and the suggestion of global military and political control in a "new world order"-that has elicited fear. Perhaps surprisingly, this response has been most intense in the most developed countries of the West which in other ways seem to be the very paradigm of globalization. In the United States, for example, the Christian Identity movement and militia organizations have been fueled by fears of a massive global conspiracy involving liberal American politicians and the United Nations. In Europe, this fear of the loss of national identity and control has led to the rise of right wing parties and stridently xenophobic ideologies (Barker 2008).

As far-fetched as the idea of a "new world order" of global control may be, there is some truth to the notion that the integration of societies, communication among disparate peoples, and the globalization of culture have brought the world closer together. Although it is unlikely that a cartel of malicious schemers has designed this global trend, its effect on local societies and national identities has nonetheless been profound. It has undermined the modern idea of the nation-state by providing nonnational and transnational forms of economic, social, and cultural interaction. The global economic and social ties of the inhabitants of contemporary global cities are linked together in a way that supersedes the Enlightenment notion that peoples in particular regions are naturally linked together in a social contract. In a global world, it is hard to say where particular regions begin and end. For that matter, it is hard to say how one should define the "people" of a particular nation.

This is where religion and ethnicity step in to redefine public communities. The fading of the nation-state and old forms of secular nationalism have produced both the opportunity for new nationalisms and the need for them. The opportunity has arisen because the old orders seem so weak; and the need for national identity persists because no single alternative form of social cohesion and affiliation has yet appeared to dominate public life the way the nation-state did in the twentieth century. In a curious way, traditional forms of social identity have helped to rescue the idea of national societies. In the increasing absence of any other demarcation of national loyalty and commitment, these old staples—religion, ethnicity, and traditional culture-have become resources for national identification.

\section{Ethnicity and Religion to the Rescue of Nationalism}

In the contemporary political climate, therefore, religious and ethnic nationalism provide a solution to the problem of secular politics and global control in a multicultural world. As secular ties have begun to unravel in the post-Soviet and post-colonial era, and a wash of new immigrants have arrived to create multicultural societies out of traditional national communities, local leaders have searched for new anchors to ground their social identities and political loyalties. Many have turned to ethnicity and religion. What is ideologically significant about these ethno-religious movements is their creativity. Although many of the framers of the new nationalisms have reached back in history for ancient images and concepts that will give them credibility, theirs are not simply efforts to resuscitate old ideas from the past. These are contemporary ideologies that meet present-day social and political needs.

In the modern context, this is a revolutionary notion-that indigenous culture can provide the basis for new political institutions, including resuscitated forms of the nation-state. Movements that support ethno-religious nationalism are, therefore, often confrontational and sometimes violent. They reject the intervention of outsiders and their ideologies and, at the risk of being intolerant, pander to their indigenous cultural bases and enforce traditional social boundaries. It is no surprise, then, that they get into trouble with each other and with defenders of the secular state. Yet even such conflicts with secular modernity serve a purpose for the movements: it helps define who they are as a people and who they are not. They are not, for instance, secularists.

Since secularism is often targeted as the enemy, that enemy is most easily symbolized by things Western. America and Europe have taken the brunt of international religious and ethnic terrorist 
attacks in recent years, in part because they so aptly symbolize the transnational secularism that the religious and ethnic nationalists loathe, and in part because they do indeed promote transnational and secular values. For instance, America has a vested economic and political interest in shoring up the stability of regimes around the world. This often puts the United States in the position of being a defender of secular governments. Moreover, the United States supports a globalized economy and a modern culture. In a world where villagers in remote corners of the world increasingly have access to MTV, Hollywood movies, and the internet, the images and values that have been projected globally have often been American.

So it is understandable that Western countries would be disdained. What is perplexing to many Americans and Europeans is why their countries would be so severely hated, even caricatured. The demonization of Western countries by many ethno-religious groups fits into a process of delegitimizing secular authority that involves the appropriation of traditional religious images, especially the notion of cosmic war. In such scenarios, competing ethnic and religious groups become foes and scapegoats, and the secular state becomes religion's enemy (Calhoun et al. 2011). Such satanization is aimed at reducing the power of one's opponents and discrediting them. By humiliating them-by making them subhuman—ethno-religious groups assert the superiority of their own moral power.

\section{The Future of Religious and Ethnic Politics in a Global World}

Movements of ethnic and religious politics are therefore ambivalent about globalization. To the extent that they are nationalistic, they often oppose the global reach of world government, at least in its secular form. But the more visionary of these movements also at times have their own transnational dimensions, and some dream of world domination shaped in their own ideological images. For this reason, one can project at least three different futures for religious and ethnic nationalism in a global world: one where religious and ethnic politics ignore globalization, another where they rail against it, and yet another where they envision their own transnational futures.

\subsection{Non-Globalization: New Ethnic and Religious States}

The goal of some ethnic and religious activists is the revival of a nation-state that avoids the effects of globalization. Many of the supporters who voted both for Brexit and U.S. Presidential candidate Donald Trump thought that they were rejecting international trade alliances and the influx of refugees from around the world. Right-wing movements in Europe that reject regional and international alliances often imagine that their nations can return to a self-sufficient economic and political order that does not rely on global networks and transnational associations.

Where new religious states have emerged, they have tended to be isolationist. In Iran, for instance, the ideology of Islamic nationalism that emerged during and after the 1979 revolution, and that was propounded by the Ayatollah Khomeini and his political theoretician, Ali Shari'ati, was intensely parochial. It was not until some twenty years later that new movements of moderate Islamic politics encouraged its leaders to move out of their self-imposed international isolation (Wright 2000). The religious politics of Afghanistan during the reign of the Taliban was even more strongly isolationist. Led by members of the Pathan ethnic community who were former students of Islamic schools, the religious revolutionaries of the Taliban established a self-contained autocratic state with strict adherence to traditional Islamic codes of behavior (Marsden 1998).

Yet religious politics need not be isolationist. In India, when Hindu nationalists in the Bharatiya Janata Party (BJP), "Indian People's Party", came to power in 1998-a victory that was consolidated in the national elections of 1999-some observers feared that India would become isolated from world opinion and global culture as a result. The testing of nuclear weapons as one of the BJP's first acts in power did little to dispel these apprehensions. But in many other ways, including its openness to economic ties and international relations, the BJP has maintained India's interactive role in the world community. Credit for this may be due, in part, to the relatively moderate leadership of the first BJP Prime Minister, Atal Bihari Vajpayee, and the later BJP Prime Minister, Narendra Modi, who saw in 
international trade alliances a way of boosting the economy. The rise of a modern Muslim government in Indonesia has also adopted a tolerant and international stance.

\subsection{Guerrilla Antiglobalism}

In other regions of the world, it is not the creation of new religious states that is at issue but the breakdown of old secular states with no clear political alternative. In some instances, religious and ethnic activists have contributed to these anarchic conditions. The rise of the Islamic State (ISIS) in Iraq and Syria in 2014 during a vacuum of political power is a terrible case in point. In the former Yugoslavia, bloodshed between rival religious communities in Bosnia and Kosovo also came in the wake of the collapse of civil order. Because these situations have been threats to world order, they have provoked the intervention of international forces.

It is, however, world order that many of these religious and ethnic nationalists oppose. They note that the increasingly multicultural societies of most urban communities around the world have undermined traditional cultures and their leaders. They have imagined the United States and the United Nations to be agents of an international conspiracy, one that they think is hell-bent on forming a homogenous world society and a global police state. This attitude towards America's global power is not only a part of the mindset of American enemies abroad, but also a part of the thinking of the U.S. homegrown terrorists, including those associated with the Alt-Right movement of xenophobic nationalism that erupted in the second decade of the 21st century. Earlier it was the specter of America's role in the new world order-graphically described in the novel, The Turner Diaries-that one of the novel's greatest fans, Timothy McVeigh, had hoped to forestall by attacking a symbol of federal control in America's heartland. His assault on the Oklahoma City federal building in 1995, along with other terrorist attacks around the world-including Osama bin Laden's alleged bombing of U.S. Embassies in Africa in 1998 and the USS Cole in Yemen in 2000-were acts of what might be considered "guerrilla antiglobalism".

\subsection{Transnational Religious and Ethnic Alliances}

Although the members of many radical religious and ethnic groups may appear to fear globalization, what they distrust most are the secular aspects of globalization. They are afraid that global economic forces and cultural values will undercut the legitimacy of their own bases of identity and power. Other aspects of globalization are often perceived by them as neutral, and in some instances, useful for their purposes.

Some groups have a global agenda of their own, a transnational alternative to political nationalism. Increasingly terrorist wars have been waged on an international and transnational scale. Even though ISIS territorial control largely ended in 2018, it was survived by a global network of jihadi activists connected by social media on the internet (Juergensmeyer 2016). Some of them continue to plot terrorist attacks on their perceived U.S. and European enemies. When the World Trade Center was demolished in the dramatic aerial assaults of 11 September 2001, it was not just America that was targeted but also the power of the global economic system that the buildings symbolized. Osama bin Ladin's al Qaeda network was itself a global structure. The global activists in the transnational networks of ISIS and al Qaeda would like to imagine themselves engaged in what the American political scientist, Samuel Huntington, called a "clash of civilizations" (Huntington 1996).

Another form of religious transnationality may emerge from the international relations of kindred religious states. According to one theory of global Islamic politics that circulated in Egypt in the 1980s and 1990s, local movements of Muslim politics were meant to be only the first step in creating a larger Islamic political entity-a consortium of contiguous Muslim nations. In this scenario, religious nationalism would be the precursor of religious transnationalism. Transnational Islam would lead to Islamic versions of such secular consortia as NAFTA and the European Community. In the Islamic model, however, the divisions among states would eventually wither away when a greater Islamic union is formed. 
A third kind of transnational association of religious and ethnic activists has developed in the diaspora of cultures and peoples around the world. Rapid internet communication technologies allow members of ethnic and religious communities to maintain a close association despite their geographic dispersion. These "e-mail ethnicities" are not limited by any political boundaries or national authorities. Many of the online supporters of ISIS are tied not only by religious affiliations but also by ethnic ones, since many are part of Algerian, Libyan, and other diasporic communities. Expatriates such as Irish Republicans, Indian Sikhs, and both Sinhalese and Tamil Sri Lankans have provided both funding and moral support to their compatriots' causes. In the case of Kurds, their "nation" is spread throughout Europe and the world, united through a variety of modern communications technologies. In some cases, these communities long for a nation-state of their own; in other cases, they are prepared to maintain their nonstate national identities for the indefinite future.

\section{Identity, Power and Globalization}

Each of these futures contains a paradoxical relationship between the national and globalizing aspects of ethno-religious politics. This suggests that there is a symbiotic relationship between certain forms of globalization and religious and ethnic nationalism. It may appear ironic, but the globalism of culture and the emergence of transnational political and economic institutions enhance the need for local identities. They also create the desire for a more localized form of authority and social accountability.

The crucial problems in an era of globalization are identity and control. The two are linked, in that a loss of a sense of belonging leads to a feeling of powerlessness. At the same time, what has been perceived as a loss of faith in secular nationalism is experienced as a loss of agency as well as identity. For these reasons, the assertion of traditional forms of religious and ethnic identities are linked to attempts to reclaim personal and cultural power. The vicious outbreaks of religious and ethnic terrorism that have occurred at the end of the 20th century and the first decades of the 21st century can be seen as tragic attempts to regain social control through acts of violence. Until there is a surer sense of citizenship in a global order, therefore, ethno-religious visions of moral order will continue to appear as attractive though often disruptive solutions to the problems of identity and belonging in a global world.

Funding: This research received no external funding.

Conflicts of Interest: The authors declare no conflict of interest.

\section{References}

Addi, Lahourari. 2017. Radical Arab Nationalism and Political Islam. Washington: Georgetown University Press.

Anderson, Benedict. 1983. Imagined Communities: Reflections on the Origin and Spread of Nationalism. London: Verso. Barker, Philip. 2008. Religious Nationalism in Modern Europe. London: Routledge.

Calhoun, Craig, Mark Juergensmeyer, and Jonathan VanAntwerpen, eds. 2011. Rethinking Secularism. New York: Oxford University Press.

Chatterjee, Partha. 1993. The Nation and Its Fragments: Colonial and Postcolonial Histories. Princeton: Princeton University Press.

Farhadian, Charles. 2005. Christianity, Islam and Nationalism in Indonesia. London: Routledge.

Gottlieb, Gidon. 1993. Nation Against State: A New Approach to Ethnic Conflicts and the Decline of Sovereignty. New York: Council on Foreign Relations.

Greenfeld, Liah, ed. 2017. The Globalisation of Nationalism: The Motive-Force Behind Twentieth-Century Politics. London: European Consortium for Political Research.

Habermas, Jurgen. 1987. Modernity-An Incomplete Project. In Interpretive Social Science: A Second Look. Edited by Paul Rabinow and William M. Sullivan. Berkeley: University California Press.

Huntington, Samuel P. 1996. The Clash of Civilizations and the Remaking of World Order. New York: Simon and Schuster. 
Hurd, Elizabeth. 2017. Beyond Religious Freedom: The New Global Politics of Religion. Princeton: Princeton University Press.

James, Paul W. 2006. Globalism, Nationalism, Tribalism: Bringing Theory Back In. London: Sage.

Judis, John B. 2018. The Nationalist Revival: Trade, Immigration and Globalization. New York: Columbia Global Reports.

Juergensmeyer, Mark. 1993. The New Cold War? Religious Nationalism Confronts the Secular State. Berkeley: University of Press.

Juergensmeyer, Mark. 2008. Global Rebellion: Religious Challenges to the Secular State. Berkeley: University of California Press.

Juergensmeyer, Mark. 2016. How ISIS Will End. Cairo Review of Global Affairs, Summer.

Juergensmeyer, Mark. 2017. Terror in the Mind of God: The Global Rise of Religious Violence, 4th ed. Oakland: University of California Press.

Juergensmeyer, Mark, Dinah Griego, and John Soboslai. 2015. God in the Tumult of the Global Square: Religion in Global Civil Society. Berkeley: University of California Press.

Kotkin, Joel. 1994. Tribes: How Race, Religion and Identity Determine Success in the New Global Economy. New York: Random House.

Marsden, Peter. 1998. The Taliban: War, Religion and the New Order in Afghanistan. London: Zed Books.

Shah, Timothy Samuel, Alfred Stepan, and Monica Duffy Toft, eds. 2012. Rethinking Religion and World Affairs. New York: Oxford University Pres.

Smith, Anthony D. 1995. Nations and Nationalism in a Global Era. London: Polity Press.

Tamir, Yael. 1993. Liberal Nationalism. Princeton: Princeton University Press.

Toft, Monica Duffy, Daniel Philpott, and Timothy Shah. 2011. God's Century: Resurgent Religion and Global Politics. New York: W. W. Norton.

Wright, Robin. 2000. The Last Great Revolution: Turmoil and Transformation in Iran. New York: Knopf.

Young, Crawford, ed. 1993. The Rising Tide of Cultural Pluralism: Nation-State at Bay? Madison: University of Wisconsin Press.

(C) 2019 by the author. Licensee MDPI, Basel, Switzerland. This article is an open access article distributed under the terms and conditions of the Creative Commons Attribution (CC BY) license (http://creativecommons.org/licenses/by/4.0/). 